\title{
Hepatitis B Virus Infection Prevalence among Patients in a Local Community Hospital in Nasarawa State, Nigeria
}

\section{Tella $\mathrm{EE}^{1}$, Attah $\mathrm{AA}^{2}$, Al Mustapha $\mathrm{FY}^{3}$, Danjuma $\mathrm{ED}^{4}$ and $\mathrm{Oti} \mathrm{VB}^{5 *}$}

${ }^{1}$ Department of Health Planning, Research and Statistics, Kaduna State Ministry of Health, Nigeria

${ }^{2}$ Department of Medical Microbiology, Ahmadu Bello University Teaching Hospital Zaria, Nigeria

${ }^{3}$ Department of Microbiology, Federal University of Lafia, Nigeria

${ }^{4}$ Inter Country Support Team, World Health Organization, South Africa

${ }^{5}$ Department of Microbiology, Nasarawa State University, Nigeria

\section{Research Article}

Volume 5 Issue 4

Received Date: September 14, 2021

Published Date: October 05, 2021

DOI: $10.23880 /$ eij-16000203

*Corresponding author: Victor Baba Oti, Department of Microbiology, Nasarawa State University, Keffi, Nigeria, Tel: 07069657739; Email: Obabavictor1@gmail.com

\section{Abstract}

Hepatitis B virus (HBV) infection is known as one of the most important public health challenges these days in Nigeria. The viral infection makes up of infectious hazards due to its risk of transmission. There is needed to keep updating the knowledge of the prevalence of HBV infection in Nasarawa state, Nigeria. Based on these premises, this study was undertaken to determine the prevalence of HBV infection among patients attending General Hospital Doma, Nasarawa State, Nigeria. This was a crosssectional study carried out over a three months period. A total of 247 patients attending the hospital were consecutively recruited for the study. Information on demographics and risk factors were obtained with a self-administered questionnaire. Rapid diagnostic test kits (ASPEN Laboratory Inc, USA) were used to detect the presence of Hepatitis B surface antigen (HBsAg). An overall prevalence of HBV infection was $17.0 \%$. HBsAg seropositivity was more in females than males $(p>0.05)$. Furthermore, the infection was highest among those aged 11-19 years (34.6\%) and lowest among those aged 30-39 years old (11.5\%). In this study, marital status, occupation, history of blood transfusion, history of HBV vaccine and scarification marks had no statistically significant association with HBV infection ( $p>0.05$ ). Although, history of blood transfusion, lack of HBV vaccination and absence of scarification marks are strong predictors in the study. This study confirmed a high endemicity of HBsAg among patients in the area. It is therefore recommended that immunization and awareness programs that mitigate the transmissibility and clinical consequences of the viral pathogen in infected patients should be advocated.

Keywords: Prevalence; HBsAg; HBV; Patients; Doma; Nigeria

Abbreviations: HBV: Hepatitis B Virus; HBsAg: Hepatitis B Surface Antigen; HCC: Hepatocellular Carcinoma; MEIA:
Micro-Particle Enzyme Immunoassay; ELF: Enhanced Liver Fibrosis. 


\section{Epidemiology International Journal}

\section{Introduction}

An infection with the Hepatitis B virus (HBV) is a public health problem and is highly endemic in the Sub-Saharan Africa (SSA) [1]. The Hepatitis B surface antigen (HBsAg) still remains the serologic hallmark of diagnosing the viral infection [2], although, Hepatitis e antigen (HBeAg), which is the soluble extractable protein is a marker for the highly infectious state of the viral infection [3]. HBV infection is restricted to the hepatocytes (liver cells) of humans and results to cirrhosis and hepatocellular carcinoma (HCC). This infection leads to a significant cases of disease burden and death [4]. Worldwide, about 2 billion persons are infected with the viral agent, 350 million persons are approximated to have chronic infection and 50 million persons are newly infected with the virus annually [5-7]. The rates of chronic HBV infection differ globally, ranging from $<1 \%$ in low endemicity places to over $30 \%$ in highly endemic places [78]. Africa is ranked the second largest number of chronic carriers of HBsAg (>8\%) after Asia [9-11].

In highly endemic areas, perinatal and horizontal routes are reasons for most transmission of the virus. But in countries where the prevalence is low, the virus is often transmitted parenterally [4,10-12]. HBV infected adults usually develop acute hepatitis and recover, while infected children seldom develop the acute situation, but 25 to $90 \%$ become chronic carriers [13]. HBV can cause both acute and chronic infections. Most infected individuals are asymptomatic during the first stage of the infection [1]. Generally, the virus has a 90 days incubation period. The acute form that is acquired newly only shows symptoms rarely [5]. Signs and symptoms of HBV infection varies with age; most under 5 years old children and newly infected immunodeficient adults often show no symptoms, while about $30-50 \%$ of persons that are above 5 years of age often show symptoms $[2,12]$. When present, the typical signs and symptoms of acute infection include; fatique, malaise, lack of appetite, vomiting, nausea, abdominal pain, fever, dark urine, joint pain, jaundice among others $[1,5]$.

The viral agent is often known as a silent killer due to the unawareness of most infected persons which make them not access medical attention in time $[3,7,11]$. Thus, early screening and appropriate therapy are major prevention and eradication strategies. Several studies have been conducted on HBV infection in Nigeria and outside the country [13-16]. There is needed to keep updating baseline information of HBV prevalence in different population especially in rural communities in Nasarawa State, Nigeria. Therefore, this study investigated HBV prevalence and associated factors among patients in Doma General Hospital, Nasarawa State. The prevalence of HBsAg was high in this population. Our findings will enhance the knowledge of the viral agent in
Nasarawa State, Nigeria with recommendations for better prevention and therapeutic formulations.

\section{Materials and Methods}

\section{Study Population}

A total of 247 patients attending General Hospital Doma were recruited in the cross-sectional survey after an informed consent was obtained from the patients. A descriptive size of the population was obtained after having approximately the necessary minimum sample size using the method proposed by Naing NN [17] at a 95\% confidence interval. Permission was sought from the management of the hospital. Data concerning the participants socio-demographic and risk factors were obtained by a self-structured questionnaire.

\section{Sample Collection}

About $5 \mathrm{ml}$ of blood specimen was drawn from each participant in the study facility by venipuncture into a plain tube and was labeled. Samples were left to clot at a minimal room atmosphere and spun at 3,000 rpm for 5 minutes. The subsequent sera were collected into well marked cryovials and kept at $-200 \mathrm{C}$ till set for analysis.

\section{HBsAg Detection}

A rapid chromatographic immunoassay test kit which is a qualitative test was used for screening the sera for HBsAg. The test kit (HBsAg one step test strips, ASPEN Laboratory Inc, USA) utilizes a combination of monoclonal and polyclonal antibodies to detect HBsAg in serum and was confirmed using the ShantestTM HBsAg ELISA (Shantha Biotechnics Ltd, India). The tests protocol and results readings were done based on the instructions of the manufacturer

\section{Ethical Approval}

In line with the Helsinki Declaration which specifies the code of ethics for biomedical research involving human subjects, clearance for this study (Ref: FMC/KF/ HREC/075/15) was obtained from the Health Research Ethics Committee (Reg. No. NHREC/21/12/2012) at the Federal Medical Centre, Keffi, Nigeria.

\section{Statistical Analysis}

The information realized from this study was subjected to descriptive statistical investigation using Smith's Statistical Package (version 2.80, Claremont, California-USA). Chisquare statistical test was used to decide association. Values obtained were reflected statistically significant at $\mathrm{p} \leq 0.05$. 


\section{Epidemiology International Journal}

\section{Results}

Out of the 247 patients that were recruited for this study, among them were 197 (79.76\%) males and 50 (20.24\%) females. An overall prevalence of Hepatitis B virus infection in this study population was $17.0 \%$. The viral infection was more in females $(22.0 \%)$ than males $(16.7 \%)$. Those patients within the age range of 11-19 years old had the highest prevalence of HBV while those aged 30-39 years reported the lowest prevalence of $11.5 \%$. The infection was higher in singles (20.2\%) than married (14.7\%). Furthermore, students reported the highest prevalence of HBV infection than other occupations in this study ( $\mathrm{P}>0.05)$. In this study, the viral infection was more among those with history of blood transfusion (20.3\%), those without history of HBV vaccination (17.4\%) and those without any form of scarification marks (17.5\%). All of the predictors studied were not statistically associated with the viral infection, although some arithmetic differences were observed within risk factors $(\mathrm{P}>0.05)$ (Table 1$)$.

\begin{tabular}{|c|c|c|c|}
\hline \multirow{2}{*}{\multicolumn{2}{|c|}{ Risk factors }} & \multicolumn{2}{|c|}{ No. Positive } \\
\hline & & HBV (\%) & p value \\
\hline \multicolumn{4}{|c|}{ Gender } \\
\hline Male & 197 & 31 (15.7) & \multirow{2}{*}{0.3825} \\
\hline Female & 50 & $11(22.0)$ & \\
\hline \multicolumn{4}{|c|}{ Age (Years) } \\
\hline$<10$ & 8 & $1(12.5)$ & \multirow{6}{*}{0.3072} \\
\hline 19-Nov & 26 & $9(34.6)$ & \\
\hline $20-29$ & 96 & $15(15.6)$ & \\
\hline $30-39$ & 78 & $9(11.5)$ & \\
\hline $40-49$ & 30 & $5(16.7)$ & \\
\hline$>50$ & 9 & $3(33.3)$ & \\
\hline \multicolumn{4}{|c|}{ Marital Status } \\
\hline Single & 104 & $21(20.2)$ & \multirow{2}{*}{0.3396} \\
\hline Married & 143 & $21(14.7)$ & \\
\hline \multicolumn{4}{|c|}{ Occupation } \\
\hline Students & 82 & $19(23.2)$ & \multirow{5}{*}{0.2469} \\
\hline Civil servants & 30 & $3(10.0)$ & \\
\hline Artisans & 61 & $12(19.7)$ & \\
\hline Unemployed & 36 & $6(16.7)$ & \\
\hline Farmers & 38 & $2(5.3)$ & \\
\hline \multicolumn{4}{|c|}{ History of Blood Transfusion } \\
\hline Yes & 79 & $16(20.3)$ & \multirow{2}{*}{0.4356} \\
\hline No & 168 & $26(15.5)$ & \\
\hline \multicolumn{4}{|c|}{ History of HBV Vaccine } \\
\hline Yes & 86 & $14(16.3)$ & \multirow{2}{*}{0.8517} \\
\hline No & 161 & $28(17.4)$ & \\
\hline \multicolumn{4}{|c|}{ Scarification Marks } \\
\hline Yes & 53 & $8(15.1)$ & \multirow{2}{*}{0.7234} \\
\hline No & 194 & $34(17.5)$ & \\
\hline
\end{tabular}

Table1: Prevalence of Hepatitis B virus Infection among patients in Doma with respect to Risk factors. 


\section{Epidemiology International Journal}

\section{Discussion}

In the present study, we found a $17.0 \%$ overall prevalence of HBsAg among patients screened for HBV infection in General Hospital Doma, Nasarawa State, Nigeria. Based on the WHO classification, the prevalence of HBV infection in this study was classified as "high". The prevalence rate in this study is lower than the $19.5 \%$ among participants in North east, Nigeria [3], correlates with $12.5-41 \%$ among patients in Maiduguri [18], and higher than rates of $8.5 \%$ reported among febrile patients in Kogi state [6], 14.0\% among patients in Sokoto [19], 12.0\% among patients in Benue [14], 5.5\% among pregnant women in Keffi [4], 5.2\% among students in Jos [15] and a low prevalence among febrile patients in Imo [20]. Studies from other countries reported different prevalence rates. For example, $6.7 \%$ were reported among students in Ghana [9], 3.9\% among patients in Ethiopia [16] and 8.5\% among HIV patients in South Africa [8]. These differences might be suggested to sample size difference, geographical variation, method of detection, cultural practice difference, and behavioral divergences for the risk factors, and the degree of HBV endemicity often correlates with the predominant mode of transmission.

Surprisingly, none of the risk factors were significantly associated with HBV infection statistically, although, there were arithmetic differences ( $p>0.05)$. However, female reported a higher prevalence $(22.0 \%)$ than males $(15.7 \%)$. Moreover, the difference between the 2 outcomes is not far but it is unconnected to the fact that females in this local community are exposed to unprotected sex with their partners and more so, they exhibit a polygamous marriage in the setting which enhances the spread of the infection. This finding finds support in reports by Pennap GR, et al. [21] among HIV patients in Keffi, Nigeria while contradicting the reports of other researchers $[6,8,20]$.

Furthermore, the infection was highest among patients aged 11-19 old (34.6\%) which could be as a result of the enhanced sexual activity of this group as well as mother to child transmission during birth. This report is in consonance with similar findings from different researchers [6,20]. Higher prevalence was also recorded among patients that were single (20.2\%). The studies by Anaele CC, et al. [20] among febrile patients in Imo, Mohammed HI, et al. [2] among subset of young people in Keffi, Nasarawa State and Isa I, et al. [22] among students in a tertiary institution in North Western Nigeria correlates with the outcome of this study. This finding might be because singles often engage in activities such as high-risk sexual activity, use of sharp objects and sharing of towel and bed sheets among others that poses high risk in the transmission of the viral agent among them.
The viral infection was highest among patients who were students (23.2\%) and least among farmers (14.7\%). Omatola $\mathrm{CA}$, et al. [6] reported no statistical association between HBV infection and occupation which correlates with our report. In our opinion, this might be the students engages in promiscuous activities that enhances the transmission of the viral agent and sharing of personal items like towel and bed sheets. History of blood transfusion was not associated with the viral infection. It was high among patients with history of blood transfusion (20.3\%). Omatola CA, et al. [6] reported blood transfusion to be associated with HBV infection. Abah HO, et al. [23] also reported similar outcome although, on different study population. This is disturbing and shows the role of blood transfusion and acquisition of HBV infection. There is need to strengthen State and National policies on blood transfusion, with a view to mitigating HBV transmission through this route. More so, the viral infection was more among those without history of HBV vaccine $(17.4 \%)$ than those that have received one or more dose of the vaccine $(16.3 \%)$.

Although, the margin of those with and without vaccine history is small, the time of taking the vaccine for those that a history of HBV immunization was not taking into account when preparing and administering the questionnaire. This report is obvious because HBV vaccine helps to mitigate the spread of the infection when the dose is taken completely [1]. The prevalence of HBV infection was not statistically significant to scarification marks but some arithmetic difference exists $(\mathrm{P}>0.05)$. The infection was higher among patients with no scars $(17.5 \%)$ than those with scarification marks (15.1\%). There is no obvious reason for this outcome, although, there are numerous dissemination routes for the virus other than through scarification. Several researchers have reported scarification marks to be one of the drives of this viral infection transmissibility routes $[2,4,8,10,23]$.

\section{Conclusion}

This study confirmed a high endemicity of HBsAg among patients in the area. History of blood transfusion, lack of HBV vaccination and absence of scarification marks are strong predictors reported in the study. It is therefore recommended that immunization and health awareness programs that mitigate the transmissibility and clinical consequences of the viral pathogen in infected patients in communities should be advocated.

\section{Limitations}

Lack of funds prevented us to carry out advanced tests on the samples such as; Micro-particle enzyme immunoassay (MEIA) or Enhanced liver fibrosis (ELF), the remaining 


\section{Epidemiology International Journal}

serologic markers other than HBsAg and HBV DNA studies. Coverage of larger sample size and other local healthcare centers in the state hindered a generalized prevalence of the infection.

\section{Acknowledgement}

The authors sincerely appreciate the efforts of the participants, Federal Medical Centre, Keffi and staff of General Hospital Doma in this study. Special thanks to Isaac B. Oti and Mrs. C. A. Oti for your advice and support. This study did not acquire any specific grant from funding agencies in the public, commercial, or not-for-profit sectors. We dedicate this study to the blessed memory of Patrick Baba Oti, PhD.

\section{Author's Contributions}

OVB conceived the study. OVB, AAA, TEE and AFY collected samples and performed the Laboratory analysis. OVB, TEE, AAA, DED and AFY did literature search. OVB and TEE did the statistical analysis and wrote the first draft of the manuscript while OVB and DED proof-read the manuscript. All authors read and approved the manuscript for publication.

\section{References}

1. Oti VB (2020) Traveler's Infections: Overview of Hepatitis B virus Infection. In: Shahid I (Eds.), Tourism, IntechOpen Publishers, Croatia.

2. Mohammed HI, Pennap GR, Oti VB, Adoga MP (2019) Markers of Hepatitis B Virus Infection in a Subset of Young People in Central Nigeria. Scientific African 5: e00121.

3. Isaac WE, Jalo I, Ajani A, Oyeniyi CO, Abubakar JD, et al. (2021) Hepatitis B envelope antigen in children and adults with Hepatitis B infection in tertiary health facility in North East Nigeria during the period of 2000-2015. J Hepat Res 6(1): 1045.

4. Oti VB, Mohammed IH, Ibrahim Y, Ibrahim C, Orok I, et al. (2021). Epidemiologic survey of HBV, HCV and HIV infections in a pregnant women population in Central Nigeria: A cross-sectional study. J Infect Dis Epidemiol 7(2): 194.

5. (2019) Hepatitis B. Fact sheets. World Health Organization.

6. Omatola CA, Onoja BA, Agama J (2020) Detection of Hepatitis B Surface Antigen among Febrile Patients in Ankpa, Kogi State, Nigeria. Journal of Tropical Medicine 2020: 1-6.

7. Lim JK, Nguyen MH, Kim WR, Gish R, Perumalswami
P, et al. (2020) Prevalence of chronic hepatitis B virus infection in the United States. Am J Gastroenterol 115(9): 1429-1438.

8. Msomi N, Naidoo K, Zuma NY, Padayatchi N, Govender K, et al. (2020) High incidence and persistence of hepatitis $B$ virus infection in individuals receiving HIV care in KwaZulu-Natal, South Africa. BMC Infectious Diseases 20: 847.

9. Tawiah PA, Yawson AA, Effah ES, Wiredu KA, Oppong K (2021) Prevalence and risk factors of hepatitis B virus infection among medical laboratory science students in a Ghanaian tertiary institution. Journal of Health Research.

10. Oti VB, Kpanja SG, Wayo JG (2018) HBsAg and Anti-HCV prevalence among apparently healthy population in Central Nigeria: A pilot study. J Transl Gastroenterol Clin Hepatol 1(1): 103.

11. Omote V, Kashibu E, Ojumah I, Adda D, Etaghane J, et al. (2018) Serological screening of HBV and HCV among patients attending a tertiary hospital in Jalingo, Taraba State, Nigeria. Saudi J Health Sci 7(3): 167-171.

12. Pennap GR, Mohammed HI, Oti VB, Adoga MP (2019) Genotype Distribution of Hepatitis B virus in a subset of infected young people in Central Nigeria. Scientific African 6: e00122.

13. Alshabi A, Fatima N, Marwan A, Oraibi KG, Qubaisi EA, et al. (2021) Epidemiology screening and genotyping analysis for Hepatitis B virus in Southwestern region of Saudi Arabia. J Infect Public Health 14(2): 187-192.

14. Mbaawuaga EM, Iroegbu CU, Ike AC (2014) Hepatitis B virus (HBV) serological patterns in Benue state, Nigeria. Open Journal of Medical Microbiology 4(1): 1-10.

15. Peters YJ, Ramyil S, Freeman DD, Isa AH, Anzaku AS, et al. (2017) Hepatitis B and C viral infections among clinical medical in Jos, North Central Nigeria. Bingham Journal of Medicine 1(1): 19-22.

16. Geta M, Yizengaw E, Getaneh Z, Getahun T (2021) Seroprevalence of hepatitis B virus infection among patients attending at Addis Alem primary Hospital, Bahir Dar, Northwest Ethiopia. Int J Gen Med 14: 405-411.

17. Naing NN (2003) Determination of sample size. Malays J Med Sci 10(2): 84-86.

18. Ajayi BB, Latbone S, Igwegbe IU, Kida IM, Goni BW, et al. (2021) Serological detection of hepatitis B and D virus co-infection among patients attending a tertiary health facility at Maiduguri, Nigeria. The Egyptian Journal of 


\section{Epidemiology International Journal}

Internal Medicine 33: 5.

19. Bello HS, Isa MA, Shettima A, Allamin IA (2013) Prevalence of serological markers for acute Hepatitis B virus among patients attending Sokoto specialist hospital, Sokoto, Nigeria. Journal of Microbiology and Biotechnology Research 3: 132-135.

20. Anaele CC, Emeonye OP, Nwatu MSB, Cosmos SA, Chukwu UJ, et al. (2021) Prevalence of Hepatitis B virus among febrile patients in General Hospital Okigwe, Imo state, Nigeria. Journal of Biosciences and Medicines 9(5): 1219.

21. Pennap GR, Oti BV, Alaribe AG, Ajegena SA, Galleh PR
(2017) Seroprevalence of hepatitis B and C viruses among HIV infected patients accessing health-care in Federal Medical Centre, Keffi, Nigeria. Journal of Advances in Microbiology 3(4): 1-6.

22. Isa I, Aminu M, Abdullahi SA, Sani MA, Esona MD (2015) Seroprevalence of hepatitis B virus in a tertiary institution in Northwestern Nigeria. African Journal of Microbiology Research 9(3): 171-179.

23. Abah HO, Aminu M (2016) Seroprevalence of hepatitis $B$ virus serological markers among pregnant Nigerian women. Ann Afr Med 15(1): 20-27.

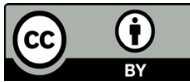

